原著

\title{
咬合位の変化が咀嚼䈘活動に及ぼす影響
}

\author{
屋 嘉 智 彦 \\ 東京医科歯科大学歯学部歯科補緅学第 1 講座（主任・指導：藍 稔教授）
}

(1994 年 3 月 9 日 受付)

\section{Effects of Occlusal Position on Masticatory Muscle Activity}

Tomohiko Yaka

The First Department of Prosthodontics, Faculty of Dentistry, Tokyo Medical and Dental University

(Chief and Director: Prof. Minoru Ai)

The effects of different occlusal position on the masticatory muscle function were investigated on 5 subjects.

Two types of maxillary stabilization splints were fabricated in order to change the occlusal position. One type of the splints was to increase the occlusal height and the other was to shift the occlusal position laterally.

The EMG activities of the masseter (M) and the anterior and posterior temporal muscles (AT, PT) were measured in various occlusal positions at $50 \%$ of maximal voluntary activity of the $\mathrm{M}$ and $\mathrm{AT}$.

The results were as follows:

1. When the occlusal height was increased,

1) The activity of the PT decreased in most subjects.

2) Asymmetry index (AI) of each tested muscle did not always indicate a similar value.

2. When the occlusal position was shifted laterally,

1) The activities of the ipsilateral AT and PT were higher than those of the contralateral side.

2) The AI of the AT and the PT changed gradually when the occlusal height was large while they changed greatly near the intercuspal position (IP) when the occlusal height was smaller. Therefore, the symmetry of the temporal muscle activity was thought to be influenced sensitively by the lateral shift of jaw position near the IP.

\section{I . 緒}

顎口腔系が機能的に正常な場合には，咬頭嵌合 位は顎関節や筋の機能と調和していると考えられ る。しかし，咬頭嵌合位は歯の咬耗や欠損，ある いは広範囲の歯冠修復や補経により变化すること
がある11。その結果，ときには顎関節や頭頸部の筋 群との間に機能的不調和が生じ，下顎運動や顎機 能の異常が発現することがある ${ }^{2,3)}$ 。そこで，どの 程度の咬頭嵌合位の変化が起こると機能的不調和 が生じるかが問題になるが，それには顎関節や筋 群の機能的許容性や生体の適応性が関係する。 
一般に，適切な咬頭嵌合位を決定するには，垂 直的および水平的な方法がとられる。垂直的には 咬合力測定による方法 ${ }^{4)}$, 顔面計測法 ${ }^{5)}$, 下顎安静 位を基準とする方法 ${ }^{6)}$ ，患者自身の感覚による方 法7)な゙が, また水平的には, 下顎の誘導による方 法 $^{8)}$, 側頭筋把握法 ${ }^{9)}$, 口腔内ゴシックアーチ描記 法 $^{10)}$, 夕ッピング運動による方法 ${ }^{11,12)}$ などが用い られる。

これらにより求められるのは筋や顎関節にとっ て機能的に好適な位置で, 上下的にも水平的にも ある範囲をもっている。その範囲内に咬頭嵌合位 が位置するのが望ましいが，この範囲は左右的に は狭いことが経験的に，またこれまでの研究に

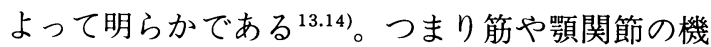
能は左右的には許容性が小さい。したがって，咬 合診断や咬合再構成にとって，この範囲の大きさ を知っておくことは重要であるが，これまで，咬 頭嵌合位付近の咬合位と顎機能との関係を定量的 に検討した報告はあまり見当たらない。

そこで著者はこうした咬合位の変化に対する筋 の許容性を把握するため, 以下の研究を行った。

\section{II. 研究方法}

習慣的閉口路および側方運動路を基準として 種々な下顎位を規定し，その位置での咬みしめを 行わせたときの筋活動を記録して各下顎位との関 係を検討した。

\section{1. 被験者}

被験者は顎口腔系に異常が認められない個性正 常咬合を有する 25 28 歳の成人男子 5 名である。

表 1 は各被験者の咬頭嵌合位から左右犬歯尖頭 位まで側方滑走運動させたときの距離を示してい る。

\section{2. 実験装置}

1）スプリントの製作

各下顎位を規定するため上顎歯列にスプリント を装着し,均等な咬合接触が得られるようにした。 被験者の上下顎歯列をシリコーン印象材で印象し たのち超硬石膏で上下顎模型を製作し，上顎歯列 模型上でワックスアップを行い，加熱重合レジン
表 1 各被験者の咬頭嵌合位か ら左右犬歯尖頭位までの距 離

\begin{tabular}{c||c|c}
\hline \hline 被験者 & 右 側 & 左 側 \\
\hline $\mathrm{A}$ & 4.4 & 5.4 \\
\hline $\mathrm{B}$ & 6.2 & 4.8 \\
\hline $\mathrm{C}$ & 5.4 & 5.6 \\
\hline $\mathrm{D}$ & 5.0 & 8.5 \\
\hline $\mathrm{E}$ & 4.0 & 0.5 \\
\hline
\end{tabular}

(単位 : $\mathrm{mm}$ )

（ジーシー社製 ACRON, No.5）を用いて全歯列型 スプリントを製作した。

2 ）下顎位の規定

各下顎位は, 下顎運動測定装置 K 6-I ダイアグ ノスティックシステム(マイオトロニクス研究所) を用いて決定した。この装置は，下顎切歯前庭部 に取り付けたマグネットの三次元的な動きをメが ネフレームで頭部に固定した 8 個のセンサーが感 知して記録解析する非接触型の下顎運動解析シス テムである。指定通りセンサーアレイを被験者の 瞳孔線およびカンペル平面に装着し, 左右側方滑 走運動および開閉口運動の軌跡を記録した後, 図 1 に示す種々の位置でスプリントの咬合調整を 行った。まず咬頭嵌合位（IP）から挙上した各下

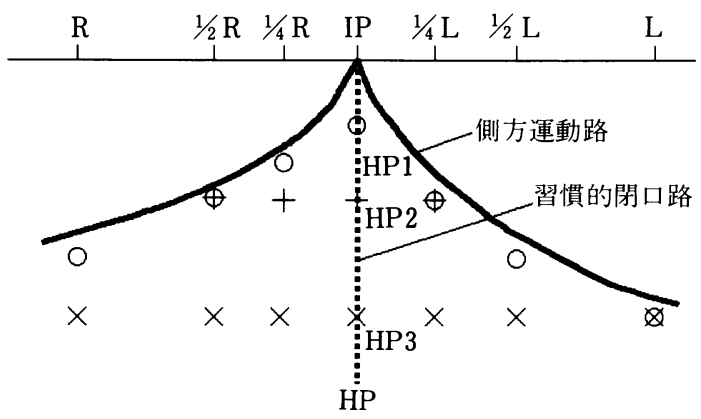

○条件 $1+$ 条件 $2 \times$ 条件 3

図 1 規定した咬合位 （前頭面よりみた側方運動路を示す） 
表 2 各被験者の HP の挙上量

\begin{tabular}{c||c|c|c}
\hline \hline 被験者 & HP 1 & HP 2 & HP 3 \\
\hline A & 1.6 & 2.6 & 4.5 \\
\hline B & 1.0 & 2.6 & 3.5 \\
\hline $\mathrm{C}$ & 1.1 & 1.5 & 2.5 \\
\hline $\mathrm{D}$ & 1.5 & 2.4 & 3.6 \\
\hline $\mathrm{E}$ & 0.8 & 1.2 & 1.7 \\
\hline \multicolumn{3}{|c}{ (単位 : $\mathrm{mm}$ ) }
\end{tabular}

顎位は，高径の最も小さいものから順に HP 1, HP 2, HP 3 とした。各被験者の HP 1, HP 2, HP 3 の挙上量を表 2 に示す。次いで側方的には, 条件 1 として可及的にわずかな量（0.1 0.5 $\mathrm{mm}$ )だけ挙上した側方運動路に沿った 7 顎位 (1) 習慣的閉口路上の位置：HP，(2)左右犬歯尖頭 位：L および R, (3)(1)-(2)の中間位：1/2L お よ び $1 / 2 \mathrm{R}$, (4)(1)-(3)の中間位： $1 / 4 \mathrm{~L}$ および $1 / 4$ $\mathrm{R})$, 条件 3 として犬歯尖頭位の高径でカンペル平
面に平行な面上にある 7 顎位（被験者 D では 5 顎 位)，そして条件 2 として前二者の上下的中間にあ る 4〜6顎位とした。これらの位置の規定は, K 6-I ダイアグノスティックシステムのモニタ画 面を被験者にみせながら，下顎を誘導して行った

(図 2 )。被験者 Eについては犬歯尖頭位までの 距離が左側で小さかったが, 右側と同じ距離だけ

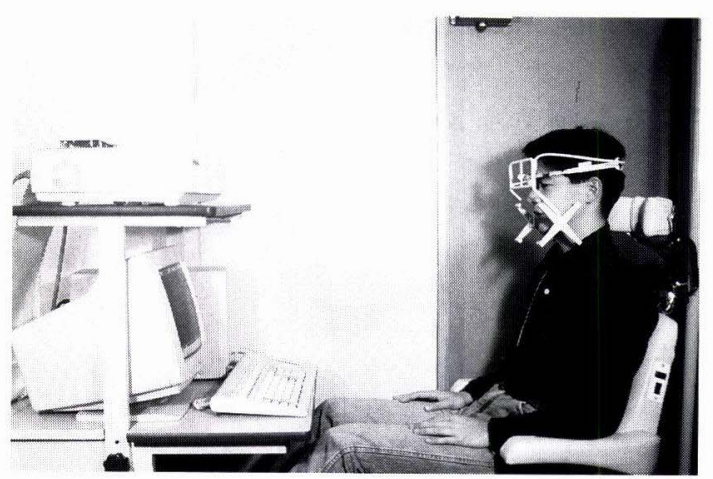

図2 下顎位の規定

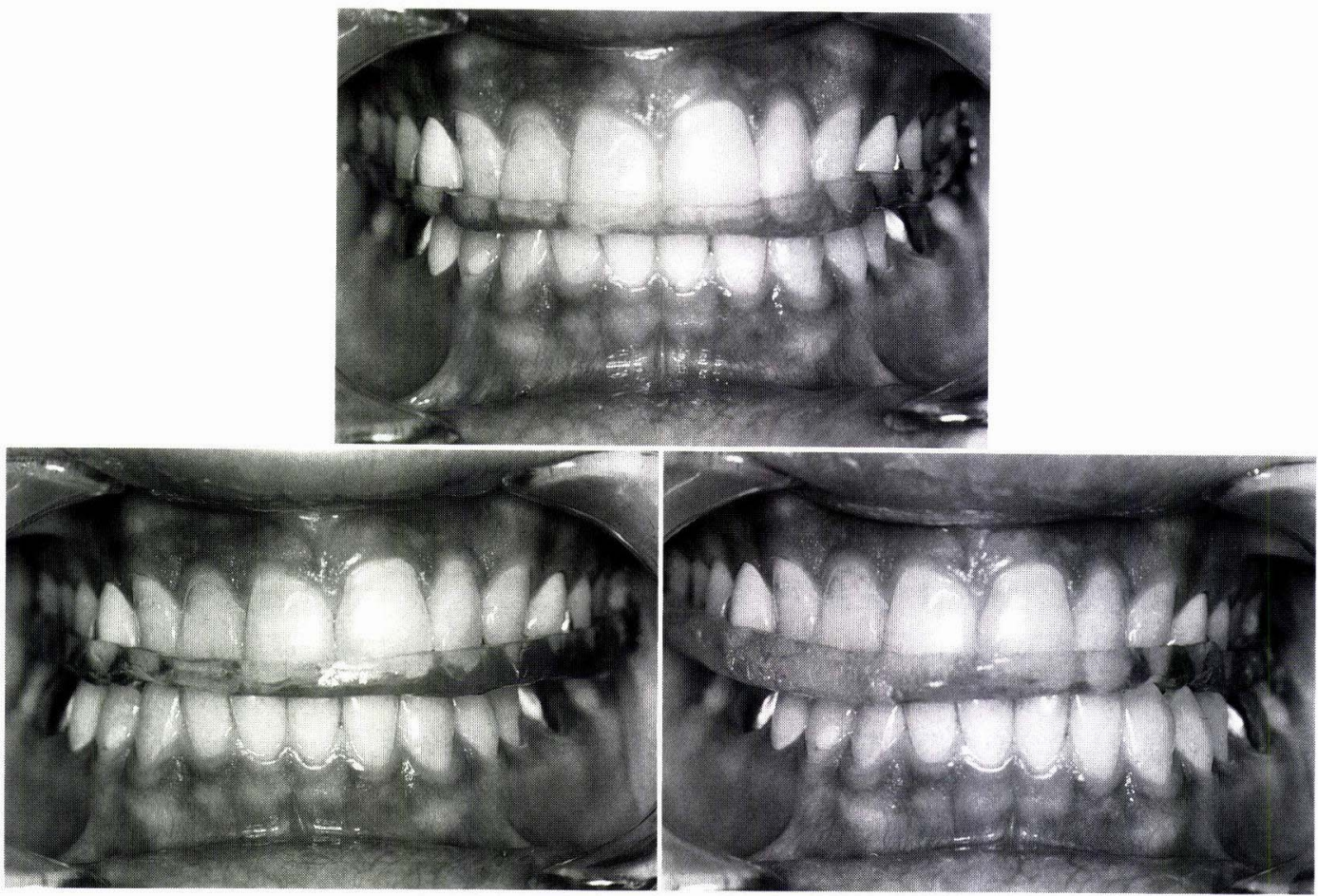

図 3 スプリント装着状態（上：HP，左下：R，右下：L) 
偏位させた位置を L とし，1/2 L，1/4 L を規定し た。罒 3 は HP, R，Lの位置でスプリントにより 下顎を固定した状態である。

\section{3 ）スプリントの調整}

上に示した各下顎位に対応したスプリントを製 作し，咬合調整を行った。条件 1 の場合のスプリ ントは咬合高径ができるだけ増加しないよう，下 顎のすべての歯と接触し, かつ接触部には穴が開 かない程度に調整した。挙上した下顎位に対する スプリントは，各々規定した高径で下顎のすべて の歯と接触するように調整した。また調整にあ たって，各スプリントの歯の接触状態はできるだ け同じになるように努めた。歯の接触の確認はシ リコーンブラック法により行い（ジーシー社製 バイトチェッカー), 上顎のスプリントと下顎のす べての歯との接触部分でシリコーンに穴があいた 状態を接触の目安とした（図 4 )。

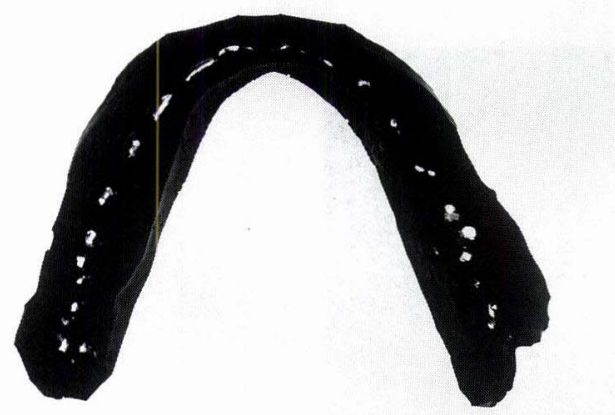

図 4 ブラックシリコーンで確認した咬合接触状態

\section{3. 筋電図記録装置}

1) 被験筋および導出方法

対象とした被験筋および部位は，左右の咬筋浅 部 (以下 $\mathrm{M})$ ，側頭筋前部（以下 $\mathrm{AT}$ )，側頭筋後 部 (以下 PT) の 6 筋である。導出方法は電極間距 離を $15 \mathrm{~mm}$ に固定した皮膚用表面電極（ユニー クメディカル社製 双極 $\mathrm{AgCl}$ 表面電極）を用いた 双極導出とし，電極は各筋に相当する皮膚上に筋 の走行と平行になるように両面テープで貼付し た。貼付部位は透明フィルムによるテンプレート
を用いて貼付位置が左右対称となるようにした。 アース電極は両耳染に貼付した。なお，電極間抵 抗をできるだけ下げるために，電極の貼付の前に 皮膚前処理剂（日本工電社製 スキンピュア）とア ルコールを用いて皮膚を十分に清拭した。

2) 増幅

表面電極により導出した筋活動電位は生体電気 現象用増幅器 (日本電気三栄社製 $1253 \mathrm{~A}$ 型)によ り増幅した。増幅器の時定数は $0.03 \mathrm{sec} と し, 1$ $\mathrm{kHz}$ のハイカットフィルターを介在させた。増幅 度は $500 \mu \mathrm{V}$ の入力に対して感熱型オムニコーダ

(日本電気三栄社製 8 M I 4) の振れが $10 \mathrm{~mm}$ に なるように調整した。

なお, 増幅器からの出力はいったんデータレ コーダ (ソニーマグネスケール社製 KS-616 型) に収録し，その後 12 ビット $\mathrm{A} / \mathrm{D}$ コンバー夕（東 京測器社製 DRA $10 \mathrm{~A}$ ) によりサンプリングタイ 厶 $500 \mu \mathrm{sec}$ で A/D変換後, パーソナルコン ピュータ（日本電気社製 PC-9801 VX上）で全波 整流し平滑化処理を行った。

3 ) 視覚的フィードバック

本実験では咬合力を大略規制するため，オシロ スコープ上に左右側 6 被験筋のうち咬筋と側頭筋 前部の 4 筋の活動総量を積分平滑化波形として表 示し，それを被験者にみせながら一定の筋活動量 となるように咬みしめを行わせた。つまり，この 4 筋の筋活動電位を生体現象用増幅器により増幅 後，積分加算ユニットを経てオシロスコープへ出 力し, オシロスコープ上でスイープスピード 0.2 sec/divの積分平滑化波形で表示した。

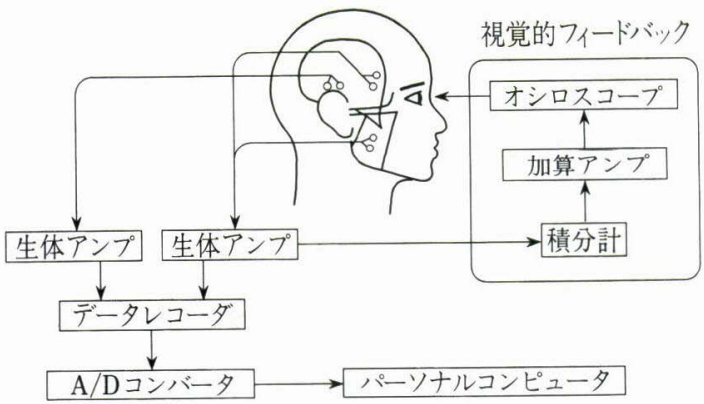

図 5 本実験のブロックダイヤグラム 
2 )，3 )のブロックダイヤグラムを図 5 に示す。

\section{4. 実験方法}

被験者を歯科用治療椅子に掛けさせ，フランク フルト平面が水平になるように頭位を調節し，以 下の項目を行わせた。

1 ）咬頭嵌合位での最大咬みしめ

最初に咬頭嵌合位（IP）での最大咬みしめを行 わせた。最大咬みしめは持続時間約 3 秒間で 1 回 行わせた。これは以後の各咬合位での咬みしめ強 さを，この時の筋活動量の $50 \%$ に設定するための 基準となるものである。

2) IP およびスプリントにより規定した各下 顎位での $50 \%$ 咬みしめ

IP での最大咬みしめを行わせた後，1 分間の休 熄をおいて，その $50 \%$ に当たる咬みしめを IP お よびスプリントで規定した各下顎位で約 3 秒間行 わせた。つまり視覚的フィードバックとしてオシ ロスコープの画面をみせて，左右咬筋および側頭 筋前部の筋活動の積分平滑化波形の波高を, IP の 場合のその波高の $50 \%$ 表示に合わせるよう咬み しめさせた。これは各下顎位につき 5 回行わせた。 なお，被験者には片側で咬まぬよう，あらかじめ 注意を与えた。

\section{5. 測定結果の分析}

\section{1) 筋活動}

記録データから各々の咬みしめについて安定し た 1.4 秒間の筋活動の積分值を求め, すべて 1 秒 間あたりの値に換算し，咬合位を垂直的に変化さ せた場合, 左右的に変化させた場合について以下 のような分析を行った。

（1）咬合位を垂直的に変化させた場合

得られた 6 筋の活動量から左右同名筋の和を求 め, 各々の筋 (M, AT, PT) の活動量として評 価を行った。なお，IP での 50\%咬みしめ時に得ら れた各筋の活動量の 5 回の平均值を 1.00 とし, 他 の各下顎位で $50 \%$ 咬みしめを行わせた時の筋活 動量をそれに対する比率で表し，これを IP 比と し, これによって各被験者, 各筋の筋活動の状況 を比較検討した。

（2）咬合位を左右的に変化させた場合
左右 6 筋の活動量についてそれぞれ評価を行っ た。ある一つの高径で下顎を側方へ偏位させた場 合，その高径の習慣的閉口路上の位置 HP での $50 \%$ 咬みしめ時に得られた各筋の活動量の 5 回の 平均值を 1.00 とし，それに対して各下顎位で 50\%咬みしめを行わせたときの筋活動量を各筋の HP 比として求めた。ただし, 条件 1 で下顎を左右 的に偏位させた場合についても同様に HP 比を 求めたが，この場合には最も高径の小さい HP 1 での $50 \%$ 咬みしめ時に得られた各筋の活動量を 基準として, 各下顎位で $50 \%$ 咬みしめを行わせた ときの各筋の活動量をそれに対する比率で求め HP 比とした。

2 ) 非対称性指数

6 筋の筋活動量から，すべての下顎位について M, AT, PT の非対称性指数 (Asymmetry Index, AI）を算出した。これは以下に示す計算式で求め, 左右の筋活動量のバランスの指標とした。

非対称性指数 $=$ $\frac{\text { 右側の筋活動量－左側の箭活動量 }}{\text { 右側の筋活動量+左側の筋活動量 }} \times 100$

\section{III. 研 究 結 果}

表 3 は, 各被験者について, 視覚的なフィード バックにより各下顎位で最大咬みしめの $50 \%$ と なるよう咬みしめを行わせたときの成績で，左右

表 3 IP での最大咬みしめの $50 \%$ となるよう視覚的 フィードバックさせたとき の成績

\begin{tabular}{c||c|c}
\hline \hline 被験者 & 平均值 & 標準偏差值 \\
\hline A & 48.7 & 0.4 \\
\hline B & 53.3 & 0.6 \\
\hline C & 49.9 & 0.9 \\
\hline D & 50.0 & 0.6 \\
\hline E & 51.5 & 0.6 \\
\hline \multicolumn{3}{|c}{ (単位:\%) }
\end{tabular}


$\mathrm{M}, \mathrm{AT} 4$ 筋の活動量を IP における最大咬みしめ 時のそれらの活動量に対する比率として表したも のである。

1. 咬合位を垂直的に変化させた場合の筋活動量 の変化

1) IP 比

M，ATは筋活動総量が規定されているため 各々の IP 比の増減は相反する関係になるが，各 筋の IP 比は，被験者 $\mathrm{E}$ 以外では咬合高径の変化 に対して類似の変化傾向を示した。図 6 は代表的 な傾向を示した被験者 $\mathrm{A}$ および $\mathrm{E} の$ 結果である。

被験者 $\mathrm{A}$

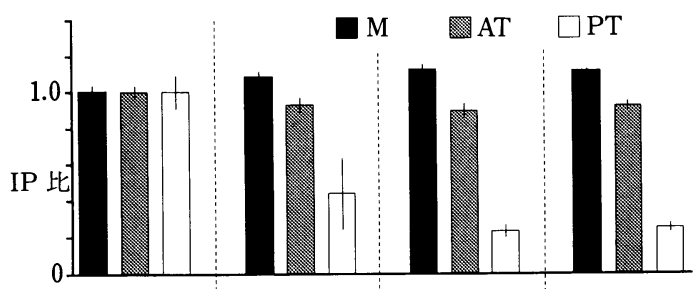

被験者 $\mathrm{E}$

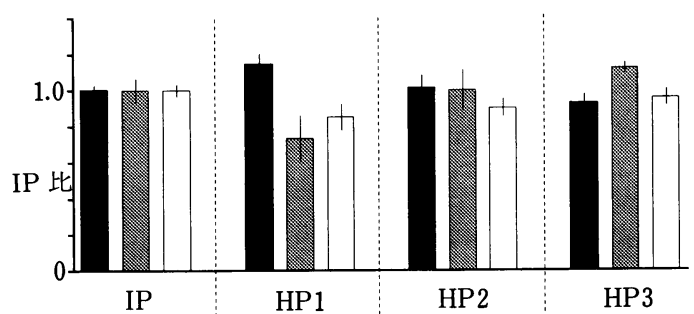

困 6 IP および挙上した各下顎位における IP 比
$\mathrm{M}$ の IP 比は, 被験者 $\mathrm{A}, \mathrm{B}, \mathrm{C}, \mathrm{D}$ では, 咬合 挙上された HP 1〜HP 3 でIPよりも值が大きく 約 1.1 1.3であった。被験者 D では高径の増加

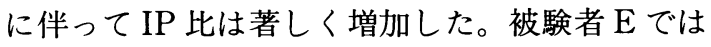
HP 1 で増加したが HP 3 ではわずかに減少し, 高 径の増加に伴い減少傾向を示した。ATの IP 比は $\mathrm{M}$ と逆の傾向を示し, 被験者 $\mathrm{A}, \mathrm{B}, \mathrm{C}, \mathrm{D}$ では高

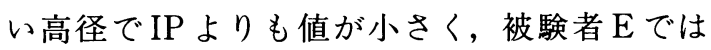
HP 1 で減少し HP 3 で増加し, 高径の増加に伴い 増加傾向を示した。PT の IP 比は, 同じ 4 被験者

被験者 $\mathrm{A}$

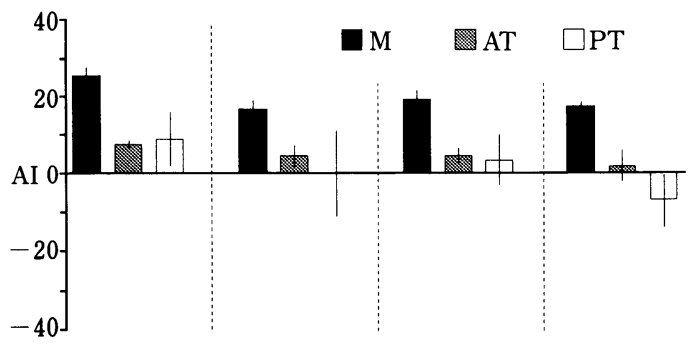

被験者B

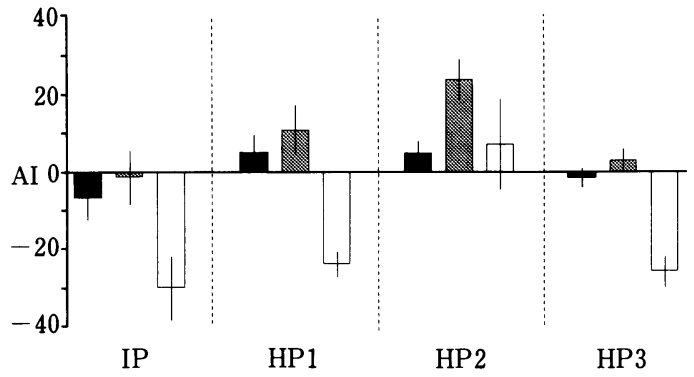

図 7 IP および挙上した各下顎位における AI

表 4 垂直的に変化させた各下顎位における全被験者の AI

\begin{tabular}{c||c|r|r|r|r|r|r|r|r|r|r|r}
\hline \multicolumn{1}{c||}{} & \multicolumn{4}{c|}{ M } & \multicolumn{4}{c|}{ AT } & \multicolumn{4}{c}{ PT } \\
\hline \multicolumn{1}{c||}{ 被験者 } & IP & HP 1 & HP 2 & HP 3 & IP & HP 1 & HP 2 & HP 3 & IP & HP 1 & HP 2 & HP 3 \\
\hline A & 25.3 & 16.3 & 18.7 & 16.9 & 7.5 & 4.6 & 4.5 & 1.7 & 8.9 & 0.0 & 3.4 & -7.2 \\
\hline B & -6.9 & 4.9 & 4.7 & -1.6 & -1.5 & 10.9 & 23.7 & 3.0 & -30.2 & -24.0 & 7.0 & -25.9 \\
\hline C & -1.6 & -8.8 & -16.7 & -4.0 & 10.8 & 17.8 & 11.0 & 5.5 & 25.5 & 40.9 & 34.3 & 11.3 \\
\hline D & -14.1 & -1.5 & 0.7 & 3.2 & -1.4 & -10.7 & -5.6 & -5.5 & -45.8 & -51.3 & -49.4 & -50.7 \\
\hline E & -27.7 & -26.4 & -9.1 & -4.7 & -6.8 & -8.2 & -27.1 & -26.3 & 3.9 & 4.9 & -4.6 & -9.0 \\
\hline
\end{tabular}




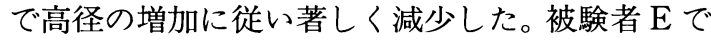
は，減少量は比較的小さかった。

2 ）非対称性指数

IP および挙上された各咬合位 HP 1 3 におけ る咬みしめ時には全被験者で各筋の AI はほとん ど 0 にはならず，さまざまな值を示した（表 4)。 図 7 は代表的な傾向を示した被験者 $\mathrm{A} ， \mathrm{~B}$ の例 である。咬合高径の増加に伴い, AIに大きな変化 がみられないもの（被験者 $\mathrm{A} ， \mathrm{C} ， \mathrm{D}$ ) と種々に変

$\mathrm{M}$ (被験者Cの条件 1)

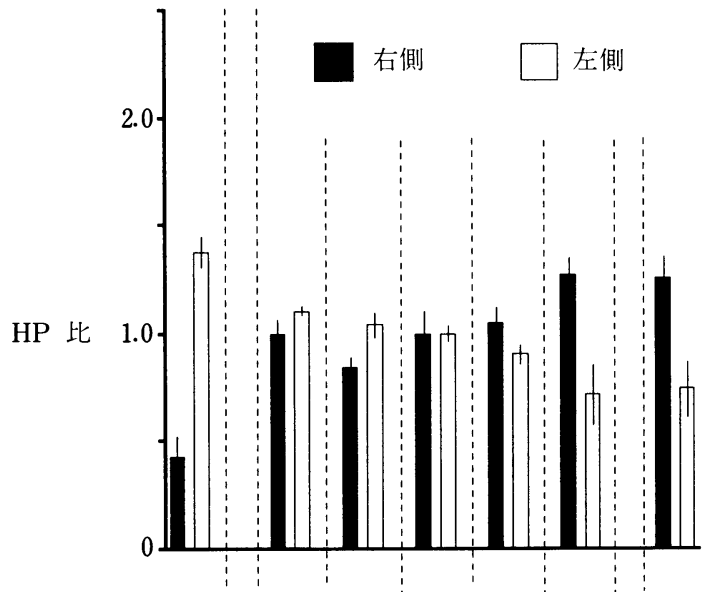

$\mathrm{PT}$ (被験者Dの条件 1)

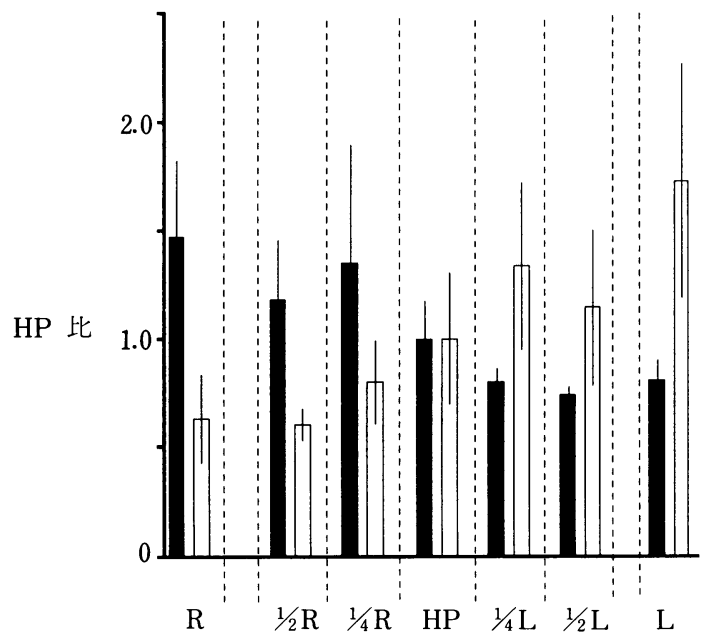

化するもの（被験者 $\mathrm{B}, \mathrm{E}$ ) の 2 つの傾向がみられ た。

\section{2. 咬合位を左右的に変化させた場合の筋活動量 の変化}

1) $\mathrm{HP}$ 比

咬合位の左右的変化に伴う各筋の HP 比の全 体的な変化傾向は, 被験者 $\mathrm{C}, \mathrm{D}$ では全条件で類似 しており，Mでは下顎の偏位側で HP 比が小さく 反对側で大きい傾向が認められ，また AT, PTで

$\mathrm{AT}$ (被験者Dの条件 1)

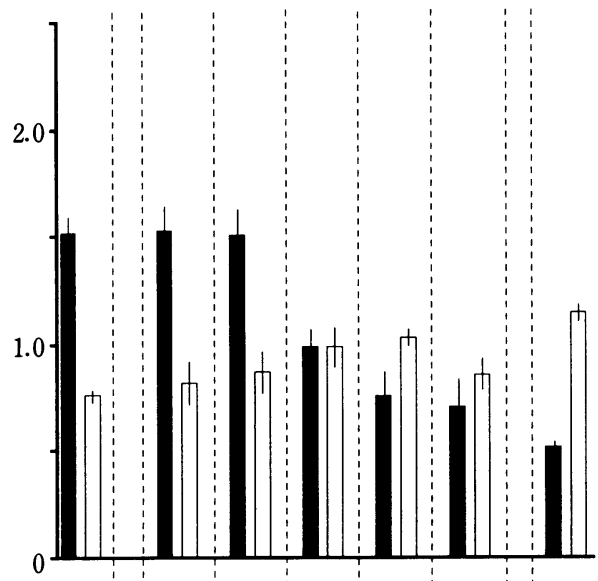

$\mathrm{AT}$ (被験者Aの条件 3)

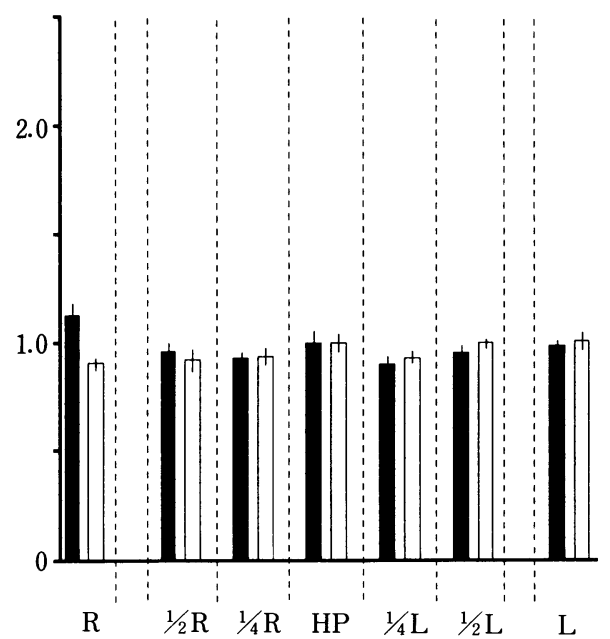

図 8 左右的に偏位させた各下顎位における HP 比 
は下顎の偏位側で HP 比が大きく反対側では小

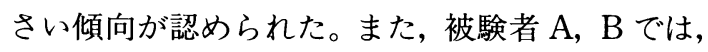
すべての条件において, M の HP 比には明らかな 変化傾向が認められず, AT, PT の HP 比は条件 1 と 2 で被験者 $\mathrm{C}, \mathrm{D}$ と同じ変化傾向を示したが, 条件 3 では咬合位の変化に対する HP 比の明ら

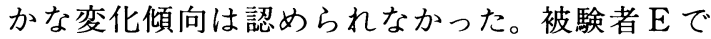
は, 条件 3 において被験者 $\mathrm{C}, \mathrm{D}$ と同じ変化傾向を 示したが，条件 $1 ， 2$ ではすべての筋の HP 比に
明らかな変化傾向が認められなかった。

図 8 は代表的な例として，条件 1 における被験 者 $\mathrm{C}$ の $\mathrm{M}$ ，被験者 $\mathrm{D}$ の $\mathrm{AT} ， \mathrm{PT}$ ，また条件 3 に おける被験者 A の ATの HP 比の変化を示した ものである。

各筋の HP 比の全体的な変化傾向は以上のよ うであるが, 細かくみると, 被験者 $\mathrm{C}$ の右側 $\mathrm{M} に$ みられるように，1/2 R の值が $\mathrm{HP}$ の值とほぼ等 しくなるほど，HP 比が咬合位の側方偏位に伴い

被験者 $\mathrm{A}$
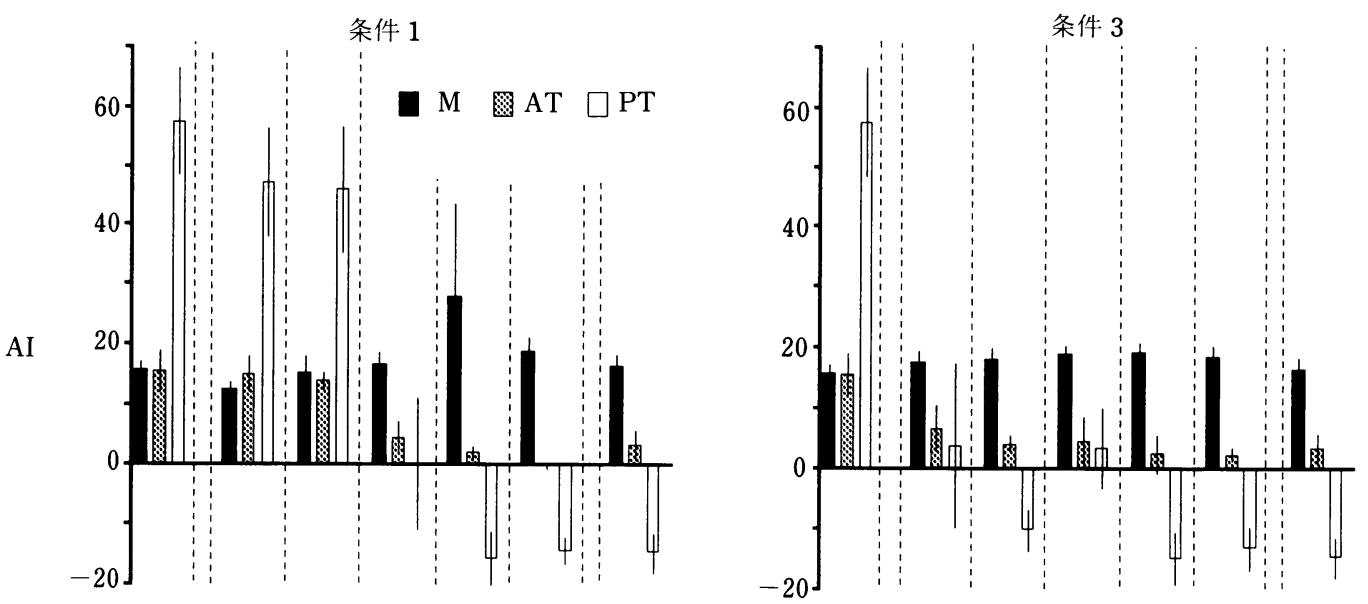

被験者 $\mathrm{E}$
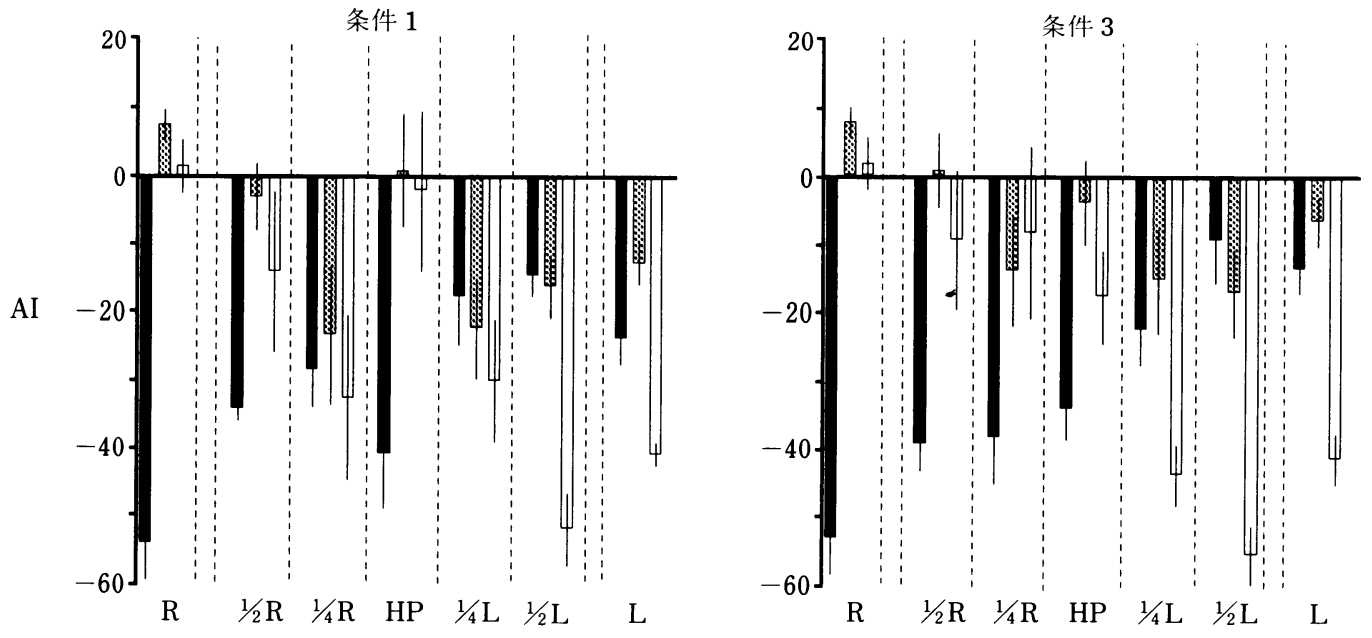

図 9 左右的に偏位させた各下顎位における $\mathrm{AI}$ 
必ずしも定常的に変化するわけではなかった。こ うした変化の状態はすべての筋で認められた。

2 ) 非対称性指数

咬合位を左右的に変化させた場合の各筋の AI を全体的にみると(表 5 )，M では，下顎の偏位の 反対側の筋活動が優位になるもの（被験者 $\mathrm{C}, \mathrm{D}$ ) と，はっきりとした傾向が認められないもの（被 験者 $\mathrm{A} ， \mathrm{~B}, \mathrm{E})$ とがあった。AT, PT では，下顎 の偏位側の筋活動が優位となった。

また，AI は HP 比とは異なり，大多数の例にお いて咬合位の側方偏位に伴った一定の変化を示し た。各条件で比較すると，条件 1 と条件 2 では類 似の傾向がみられ，AT，PTの AI は HP 付近で 大きく変化する傾向を示した。それに対して，条 件 3 ではそうした傾向が認められず， $1 / 2 \mathrm{R}$ から $1 / 2$ L まで大差ない值を示すもの（被験者 A， B ) や， R から L までほぼ同じ割合で減少するもの

（被験者 C，D）がみられた。

図 9 には咬合位を左右的に変化させた場合の $\mathrm{AI}$ の変化傾向について条件 1 , 条件 3 の典型例と して被験者 $\mathrm{A}$ ，および異なる傾向が認められた被

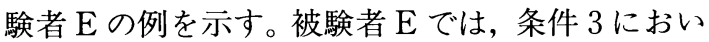
ては, AI は他の被験者と同様の傾向を示したが, 条件 1 では図に示すようにはっきりとした傾向を 示さず，条件 2 では条件 1 と条件 3 との中間的な 傾向を示した。

\section{IV．総括ならび考察}

\section{1. 研究方法}

1）下顎位の規定

本研究では咬合位の変化が咬筋, 側頭筋の筋活 動にいかなる影響を与えるかを調べるため，側方 運動路を基準として左右犬歯尖頭位にあたる咬合 高径までの範囲内で種々な下顎位を規定した。犬 歯尖頭位は下顎の機能運動に直接関係する下顎位 ではないが，上下犬歯尖頭に咬耗がみられること が多く，ブラキシズムにおいて頻繁にとられる下 顎位である。そこで本研究の対象として, 上限は 側方運動路とし, 垂直的, 左右的には犬歯尖頭位 までの範囲の下顎位とした。
側方運動路に沿った下顎位では全歯列の咬合接 触を得るため, 最小限の厚さでスプリントを調整 し，各々の下顎位に対して条件 1 とした。条件 3 は左右の犬歯尖頭位で高径が大きいほうに対応し た位置で，被験者により異なり1.7〜4.5 mm の 高径である。条件 2 は条件 3 の高径の 60 ～70\%に 相当する下顎位である。また, 左右的には咬頭嵌 合位から左右の犬歯尖頭位までの距離 $1 / 2,1 / 4$ 偏 位した位置を規定した。

下顎位の決定には K 6-I ダイアグノスティック システムを用いたが，これは非接触型下顎運動解 析用コンピュータシステムで, 被験者の違和感が 少なく, 三次元で計測でき, 操作が比較的簡便で ある。このシステムの出力特性は, $20 \times 20 \times 20$ $\mathrm{mm}$ の立方体の面上での最大誤差が $5.4 \%$ と報告 されており ${ }^{15)}$ ，本研究における下顎位の規定に必 要な範囲では，精度的に問題ないと判断された。 なお下顎位の決定に際して，マグネットのセンサ に対する位置はこのシステムの歪みの少ない範囲 を有効に使うように設定した。

2 ）筋活動の測定および分析

筋活動の記録のための動作として, 強さを規定 した咬みしめを用いた。通常, 筋活動の記録には 下顎安静位や咬みしめなどの静的条件，あるいは タッピングや種々な下顎運動などの動的条件が用 いられるが，タッピング等の動的条件では，その 終末点である咬合位の変化により, 下顎運動の均 一性が失われ ${ }^{16)}$ 筋活動の測定がしにくくなると考 えられた。そのため, 本実験では静的条件として の咬みしめを用いることにした。

また本研究ではスプリントにより咬合接触を与 えるため, 直接咬合力の測定は行えない。そこで, 各咬合位における咬みしめの強さの規定には, 左 右の咬筋および側頭筋前部の筋活動量の和を指標 として用いた。咬合力と咀嚼筋活動の関係を調べ

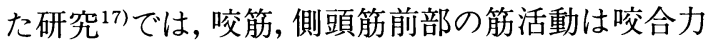
と平行しているが，側頭筋後部の筋活動は咬合力 と平行しないことが指摘されている。また, 側頭 筋後部の筋活動量は咬合高径の増加に伴い, 著し い影響を受けて減少することが本研究の予備実験 
表 5 左右的に変化させた各下顎位における全被験者の $\mathrm{AI}$

\begin{tabular}{|c|c|c|c|c|c|c|c|c|}
\hline 被験者 & 条件 & $\mathrm{R}$ & $1 / 2 \mathrm{R}$ & $1 / 4 \mathrm{R}$ & HP & $1 / 4 \mathrm{~L}$ & $1 / 2 \mathrm{~L}$ & $\mathrm{~L}$ \\
\hline \multirow{3}{*}{ A } & 1 & 15.6 & 12.3 & 15.1 & 16.3 & 27.8 & 18.7 & 16.1 \\
\hline & 2 & & 12.3 & 14.2 & 16.9 & 18.6 & & \\
\hline & 3 & 15.6 & 17.3 & 18.2 & 18.7 & 18.8 & 18.1 & 16.1 \\
\hline \multirow{3}{*}{ B } & 1 & -2.7 & -7.4 & 1.9 & 4.9 & 9.4 & 4.5 & -2.4 \\
\hline & 2 & -2.7 & & 1.9 & 4.7 & 1.0 & 4.5 & \\
\hline & 3 & -3.1 & -3.3 & 2.7 & -1.6 & 3.8 & 3.8 & -2.4 \\
\hline \multirow{3}{*}{ C } & 1 & -58.6 & -13.9 & -18.7 & -8.8 & -1.1 & 20.7 & 17.6 \\
\hline & 2 & & -13.9 & -21.7 & -16.7 & -1.1 & & \\
\hline & 3 & -21.2 & -19.4 & -11.7 & -4.0 & -6.0 & 3.8 & 17.6 \\
\hline \multirow{3}{*}{ D } & 1 & -11.5 & -15.3 & -21.2 & -1.5 & 9.1 & 15.5 & 18.2 \\
\hline & 2 & & -15.3 & -8.9 & 0.7 & 8.4 & 15.5 & \\
\hline & 3 & -11.5 & & 0.1 & 3.2 & 8.4 & & 18.2 \\
\hline \multirow{3}{*}{ E } & 1 & -54.1 & -33.9 & -28.2 & -40.8 & -17.4 & -14.3 & -23.4 \\
\hline & 2 & & -33.9 & -28.2 & -28.8 & -18.9 & -8.0 & -18.5 \\
\hline & 3 & -54.1 & -39.9 & -39.0 & -34.6 & -22.9 & -9.5 & -13.7 \\
\hline
\end{tabular}

\begin{tabular}{|c|c|c|c|c|c|c|c|c|}
\hline \multicolumn{9}{|c|}{$\mathrm{AT}$} \\
\hline 被験者 & 条件 & $\mathrm{R}$ & $1 / 2 \mathrm{R}$ & $1 / 4 \mathrm{R}$ & HP & $1 / 4 \mathrm{~L}$ & $1 / 2 \mathrm{~L}$ & $\mathrm{~L}$ \\
\hline \multirow{3}{*}{ A } & 1 & 15.5 & 15.1 & 13.9 & 4.6 & 2.0 & -0.1 & 3.4 \\
\hline & 2 & & 15.1 & 13.2 & 1.7 & -3.0 & & \\
\hline & 3 & 15.5 & 6.6 & 3.6 & 4.5 & 2.5 & 2.4 & 3.4 \\
\hline \multirow{3}{*}{ B } & 1 & 15.9 & 22.5 & 19.9 & 10.9 & 10.8 & -4.0 & 2.8 \\
\hline & 2 & 15.9 & & 24.2 & 23.7 & -0.5 & -4.0 & \\
\hline & 3 & 14.2 & 13.4 & 16.9 & 3.0 & 11.2 & 4.0 & 2.8 \\
\hline \multirow{3}{*}{ C } & 1 & 26.2 & 26.8 & 20.2 & 17.8 & 5.0 & 1.9 & -9.0 \\
\hline & 2 & & 26.8 & 16.0 & 11.0 & 5.0 & & \\
\hline & 3 & 32.4 & 22.3 & 16.3 & 5.5 & 9.1 & 1.0 & -9.0 \\
\hline \multirow{3}{*}{ D } & 1 & 23.2 & 19.6 & 16.1 & -10.7 & -25.7 & -20.5 & -45.8 \\
\hline & 2 & & 19.6 & 15.9 & -5.6 & -29.2 & -20.5 & \\
\hline & 3 & 23.2 & & -4.7 & -5.5 & -12.9 & & -45.8 \\
\hline \multirow{3}{*}{$\mathrm{E}$} & 1 & 7.7 & -2.8 & -23.0 & 1.2 & -22.1 & -15.9 & -12.2 \\
\hline & 2 & & -2.8 & -23.0 & -4.8 & -21.3 & -15.5 & -16.0 \\
\hline & 3 & 7.7 & 0.8 & -14.2 & -4.0 & -15.5 & -17.4 & -6.7 \\
\hline
\end{tabular}

PT

\begin{tabular}{c||c|r|r|r|r|r|r|c}
\hline \hline 被験者 & 条件 & $\mathrm{R}$ & $1 / 2 \mathrm{R}$ & \multicolumn{1}{c|}{$1 / 4 \mathrm{R}$} & \multicolumn{1}{c|}{$\mathrm{HP}$} & $1 / 4 \mathrm{~L}$ & $1 / 2 \mathrm{~L}$ & $\mathrm{~L}$ \\
\hline \multirow{4}{*}{$\mathrm{A}$} & 1 & 57.6 & 47.2 & 46.1 & 0.0 & -15.7 & -14.3 & -14.8 \\
\cline { 2 - 9 } & 2 & & 47.2 & 51.9 & -7.2 & -22.6 & & \\
\cline { 2 - 9 } & 3 & 57.6 & 3.8 & -11.4 & 3.4 & -14.9 & -13.2 & -14.8 \\
\hline \multirow{4}{*}{$\mathrm{B}$} & 1 & 35.2 & 24.1 & 36.6 & -24.0 & -39.0 & -38.1 & -56.3 \\
\cline { 2 - 9 } & 2 & 35.2 & & 20.9 & 7.0 & -36.3 & -38.1 & \\
\cline { 2 - 9 } & 3 & -4.8 & -21.7 & -17.8 & -25.9 & -25.7 & -30.5 & -56.3 \\
\hline \multirow{4}{*}{$\mathrm{C}$} & 1 & 78.9 & 49.6 & 52.9 & 40.9 & -3.7 & -22.4 & -35.6 \\
\cline { 2 - 9 } & 2 & & 49.6 & 50.6 & 34.3 & -3.7 & & \\
\cline { 2 - 9 } & 3 & 67.6 & 40.5 & 43.3 & 11.3 & 18.9 & -16.1 & -35.6 \\
\hline \multirow{4}{*}{$\mathrm{D}$} & 1 & -15.3 & -25.6 & -32.5 & -51.3 & -67.1 & -64.4 & -72.7 \\
\cline { 2 - 9 } & 2 & & -25.6 & -42.0 & -49.4 & -66.2 & -64.4 & \\
\cline { 2 - 9 } & 3 & -15.3 & & -47.8 & -50.7 & -60.9 & & -72.7 \\
\hline \multirow{4}{*}{$\mathrm{E}$} & 1 & 1.8 & -13.7 & -32.3 & -1.9 & -29.8 & -51.7 & -40.7 \\
\cline { 2 - 9 } & 2 & & -13.7 & -32.3 & -23.9 & -41.7 & -43.5 & -47.2 \\
\cline { 2 - 9 } & 3 & 1.8 & -9.7 & -8.5 & -18.0 & -44.6 & -56.3 & -42.2 \\
\hline
\end{tabular}


で明らかであった。これらのことから，ここでは 左右咬筋および側頭筋前部の 4 筋を咬みしめ強さ の規定に用いることにした。

咬みしめの強さに関しては, 最大咬みしめが比 較的再現性がよいといわれている。しかし，多く の下顎位で繰り返し咬みしめを行わせる必要から 最大咬みしめでは疲労による筋活動の変動が避け られない。また弱い咬みしめでは被験者が, 意識 的に左右の筋活動の調節を行うことが少なくな い。したがって，機能的な筋活動の範囲内で強い 咬みしめを行わせることが望ましい。Clarke ら ${ }^{18)}$ は, 睡眠時のブラキシズム時の咬みしめが最大咬 みしめ時の筋活動量の $66 \%$ に達すると報告して いる。そこで本実験では，この大きさ付近を機能 的範囲の限界とみて，これよりやや小さい $50 \%$ を 咬みしめ強さの基準とした。

咬みしめを行わせる場合, 力の加え方が左右の 筋活動量に影響することが知られている19)。よっ て, 実験に際して, 被験者にはできるだけ垂直方 向に咬みしめるよう指示した。

筋活動量の分析方法としては, その有効性に一 定の評価が得られている積分値を用い, さらに各 高径で各筋間の活動状況の比較を行いやすくする ために，咬頭嵌合位や習慣的閉口路上の咬合位に 対する比（IP 比, HP 比) を求めた。また, 左右 の筋活動量のバランスを表す指標として非対称性 指数 (AI) を用いた ${ }^{20)}$ 。

\section{2. 研究結果}

1) 咬合位の垂直的な変化に対する筋活動量の 変化

\section{(1) IP 比}

多くの被験者では, 挙上した咬合位における IP 比は M で大きな值を示し ATでは小さかった が，その程度には個人差がみられた。Visser ら ${ }^{21)}$ は，IPおよびスプリントにより 1 2 mm, 4〜5 $\mathrm{mm}$ 挙上した咬合位で, 最大咬みしめ時の $10 \%$ お よび $50 \%$ の強さで咬みしめさせた場合の $\mathrm{M}$, $\mathrm{AT}, \mathrm{PT}$ の活動量の変化を調べているが，50\%咬 みしめ時には，挙上した咬合位で AT の平均活動 量はわずかに減少傾向を示した。本実験では, AT
の活動量が咬合位の挙上に伴いわずかに減少した ものが被験者 5 人中 3 人，明らかに減少したもの が 1 人, 明瞭な傾向を示さなかったものが 1 人で, 全体の傾向としはVisser らと同様の結果が得ら れたといえる。一方, PTの活動量は, 本実験では Visser らの結果とは異なり, 被験者 5 人中 4 人で 小さな高径の咬合位においても著しく減少した。 しかし, 被験者 Eでは挙上された HP 1 3の咬 合位における PTの活動量は, IPに比べ低かった ものの他の被験者にみられるような減少傾向は示 さなかった。この理由として，この被験者は他と は異なり, PT の活動量が IP でもきわめて低いこ と, また咬合挙上量が他の被験者より小さく，最 も挙上量の大きな HP 3 でも $1.7 \mathrm{~mm}$ であったこ とが関係していると考えられる。この被験者につ いては予備実験で $1.5,4.0,6.5 \mathrm{~mm}$ の高径にお ける IP 比の変化を調べたところ, 4.0, $6.5 \mathrm{~mm}$ で は活動量が減少傾向を示した。したがって，本実 験でもさらに高径を増せば PT の活動量は他の被 験者同様, 減少傾向を示すことが推測される。

(2) 非対称性指数

咬合位を垂直的に変化させたときの左右の筋活 動バランスを非対称性指数 AI でみた場合, IP で は AI は 0 とならず，各筋は左右対称的には活動 しないことがわかった。正常者において AI が IP で 0 にならないことは, Naeije ら ${ }^{20)}$, Ferrario

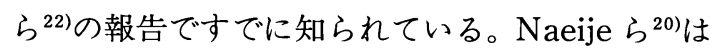
健常有歯顎者にIP で種々の強さの咬みしめをさ せたとき， M, AT の AI が咬みしめ強さにより変

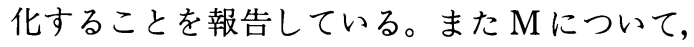
$50 \%$ 咬みしめ時には筋の断面積の大きい側，また 臼歯部の接触個所の多い側で活動量が大きいこと を報告している。本実験結果にもこのような因子 が関係しているかも知れない。

また，本実験で高径を増したときに AI は大部 分の場合 0 とならないばかりでなく，IPの AIに も必ずしも近似しないことがわかった。IPにおけ る $\mathrm{AI}$ と挙上した各咬合位における $\mathrm{AI} の$ 違いに は，下顎の挙上による筋機能の差違が関係してい ると考えられる。しかし, 後者がスプリントによ 
る咬合位であるため, 歯の接触の違いも関係して いるかもしれない。各スプリントにおける咬合接 触はできるだけ同じになるように調整されてはい るが，微妙な違いは避けられない。しかし，スプ リントにより得られた HP 1 3 各咬合位間で比 較すると, 被験者 B の例（図 7 ）で示したように $\mathrm{AI}$ の違いが顕著に認められた。したがって, AIの 変化には，接触の違いの関与は否定できないもの の下顎の垂直的位置の違いが関係しているといえ るだろう。

2 ）咬合位の左右的な変化に対する筋活動量の 変化

(1) HP 比

咬合位の左右的な変化に対する筋活動量は，各 被験者, 各条件で異なる傾向を示したが，挙上量 の小さい条件 $1 ， 2$ においては， $\mathrm{M}$ では 2 人の被 験者で下顎の偏位側で HP 比が減少し, 反対側で 増加する傾向が認められたが，他の 2 人でははっ きりとした傾向が認められなかった。また $\mathrm{AT}$, $\mathrm{PT}$ ではこの 4 人の下顎の偏位側で HP 比が増加

し，反対側で減少する傾向が認められた。

スプリントなどの装置を用いて，左右的な偏心 位ですべての歯を咬合させたときの咀嚼筋活動を 調べた研究は, 坂本 ${ }^{23)}, \mathrm{McC}$ arroll ら ${ }^{24)} に よ り$ 行わ れている。坂本はレジンスプリントにより本実験 と同様に下顎を偏位させた位置ですべての歯を咬 合させ，弱い咬みしめと最大咬みしめを行わせた ときの各位置での左右同名筋の活動量の大きさを 比較検討している。その結果，弱い咬みしめでは M，AT，PT ともに偏位側では非偏位側よりもや や大きな活動量が認められ，最大咬みしめでは多 くの例で M, AT, PT とも偏位側に著しい活動が 認められたが，M では逆の傾向を示す例があった と述べている。本実験の咬みしめ強さは䛀本が用 いた 2 種の咬みしめ強さの中間的な強さに相当 し，また規定した位置については本実験の条件 1 が相当すると考えられる。本実験の各咬合位にお ける活動量を坂本と同様に左右同名筋間で比べる と, AT, PT では偏位側の筋活動が大きく, 非偏 位側では小さい傾向が認められ，M では被験者に
より傾向が分れた。これは，坂本の結果と一致す る。

（2） 非対称性指数

HP 比は咬合位の左右的偏位に伴い必ずしも一 定の変化傾向を示さなかったが，各筋の非対称性 指数 $\mathrm{AI}$ を指標とした場合には，被験者 $\mathrm{E}$ を除い た 4 人の被験者では，その值に咬合位の偏位に伴 う明瞭な変化傾向がみられた。すなわち，AT と PT では偏位した側の筋活動が反対側のそれより 優位となり，Mでは被験者により変化がみられな いものもあったが, 明瞭な変化を示したものでは, $\mathrm{AT} ， \mathrm{PT}$ とは逆に偏位反对側の筋活動が優位と なった。これは, 前述のように坂本 ${ }^{23)}$ が左右同名箭 間で活動量を比較した結果に相当する。このよう に咬合位の左右的偏位に伴って HP 比としては 一定の傾向がみられないが $\mathrm{AI} て ゙ は$ 明瞭な変化傾 向が認められたことの理由としては，次のように 考えられる。つまり, HP 比が各筋の活動量につい て各咬合位の值を HP と比較しているのに対し て, AI は各咬合位について左右同名筋間で活動量 を比較していることから AI では左右的な各筋の わずかな差異が明瞭に示された結果であろう。

被験者 $\mathrm{E} て ゙ は$ 条件 1 と条件 2 における HP 比 や $\mathrm{AI}$ に他の被験者と異なる傾向が認められた が, この被験者では, 表 1 に示したように, IP か ら左側の犬歯尖頭位までの距離が著しく小さい。 このため, 右側と同じ距離だけ下顎を左側へ偏位 させた位置を L としたが，挙上量が少ない条件 $1 ， 2$ では位置 L をとると，上下顎の歯列は交叉 した位置関係となり不安定な咬合状態となった。 したがって，この位置での咬みしめ時には，咬み しめのための筋活動よりも下顎を安定させるため の協調的な筋活動が大きく作用したと考えられ る。咬合高径が大きい条件 3 では他の被験者と同 様の $\mathrm{AI}$ の傾向を示したが，これは安定して咬み しめが行えた結果と考えられる。

例外的な傾向を示した被験者 $\mathrm{E}$ を除く 4 人に ついて，各条件間で AT, PTの AI の変化傾向を 比較すると，咬合高径が小さい条件 1 では咬合位 の偏位が小さいところで AI の変化が現れ，咬合 
高径が大きい条件 3 では咬合位の偏位が大きく なってから $\mathrm{AI}$ の変化が現れはじめる傾向があっ た。すなわち，高径が小さい場合には，下顎の左 右的な偏位に対する筋活動の均衡性が鋭敏である ことが示唆された。

そこで, 条件 1 と条件 3 について, $\mathrm{AI}$ がどの位 置で最も大きく変化するかを知るため, $\mathrm{AI}$ の変化 度を求めた。 $\mathrm{AI}$ の変化度は, 次に示すように偏位 した各咬合位における AI と HPにおける AI と の差を各咬合位の HP からの側方距離の比，つま り L， R では 4，1/2 L，1/2 R では $2 ， 1 / 4 \mathrm{~L} ， 1 /$
4 R では 1 で除したものである。

$\mathrm{AI}$ の変化度 $=$

側方偏位位置での AI-HP での AI

HP から側方偏位位置までの距離比

図 10 にその代表例として被験者 A, D の場合 を示す。咬合位の左右的変化に対する AT, PT の $\mathrm{AI}$ は, 条件 1 の $1 / 4 \mathrm{R}$ から $1 / 4 \mathrm{~L}$ の狭い範囲で大 きく変化しており, AI が IP 付近の下顎位の左右 的変化に対して鋭敏であることがわかる。しかし 条件 3 では, 大多数の例で IP 付近の $\mathrm{AI}$ の変化は 小さかった。

被験者 $\mathrm{A}$
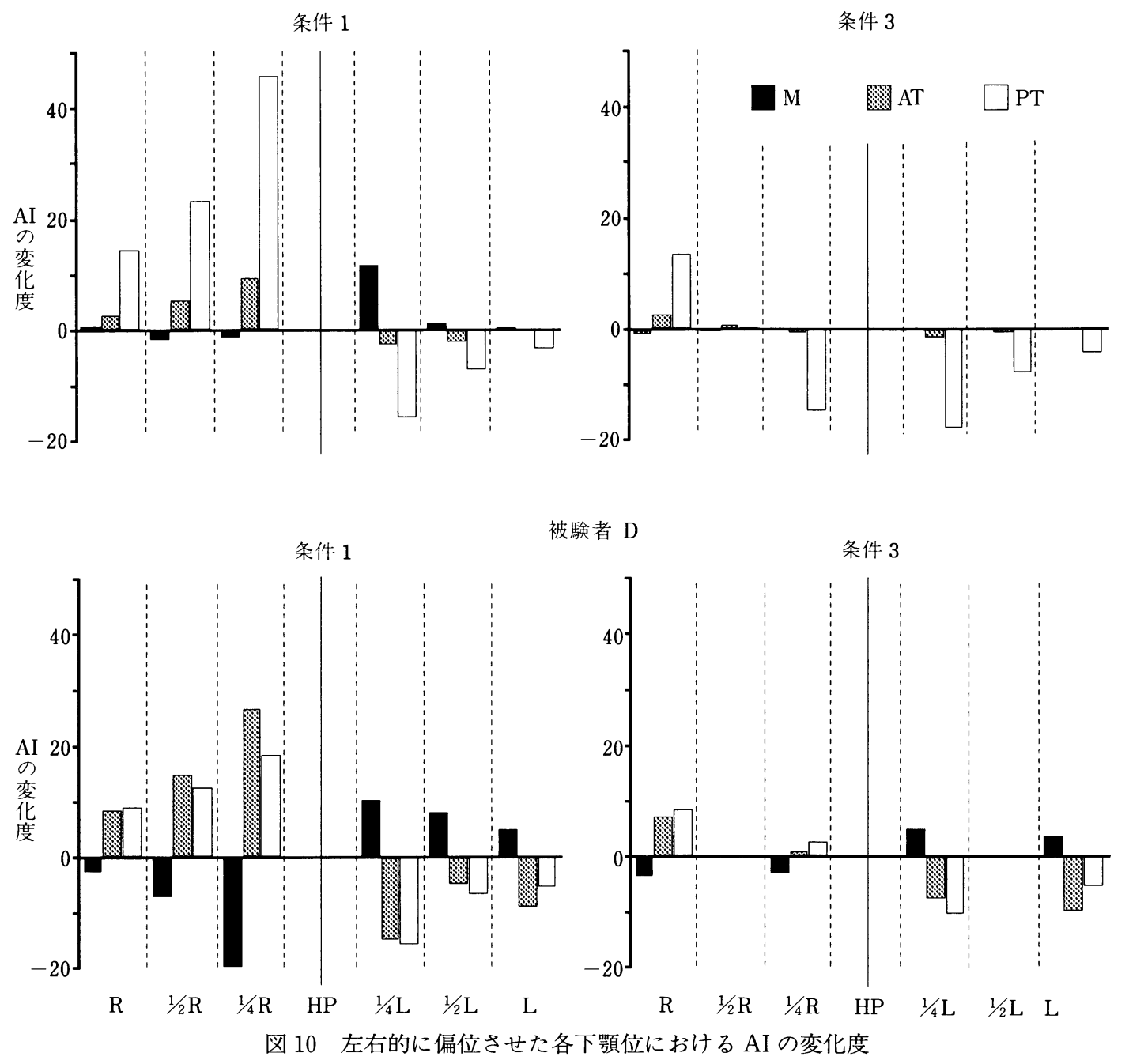

(91) 
3 ）咬合位の垂直的，左右的な変化に対する筋 の反応

咬合位が垂直的に変化する場合, 高径の増加に 伴い M, AT では活動量の変化が小さかったが, PTでは減少した。これはVisser らの研究でも 10\%の咬みしめ強さで認められているが，PTの 走行に対して咬合挙上により咬合力の負荷の方向 が変わることが関係しているのかも知れない。

咬合位を左右的に偏位させた場合, AT, PT は 偏位側の筋活動が増加し, 反対側では減少した。 古屋 ${ }^{25)}$ は, 口蓋部で下顎を一点支持させ, 下顎を側 方に偏位させて $20 \mathrm{~kg}$ の咬合力で咬みしめさせた 研究で, 偏位側の AT, PT の活動量が大きいとの 結果を得, 下顎の側方偏位に伴う左右的な筋力の 調整は主として側頭筋が行っていると考察してい る。その根拠として，咀嚼筋の筋紡錘の多くが側 頭筋に集中し，特に垂直部と水平部に分布してい ることを挙げ，このことは筋力に関する自己受容 性が高いことを意味すると述べている。本研究の 結果も古屋のそれと類似し，同様のことが推察さ れる。さらに本研究では, 側頭筋の筋活動の変化 は，左右的にも垂直的にも咬頭嵌合位付近の高径 において著しいことがわかった。側頭筋がこのよ うな変化を示すのは，筋紡錘の影響だけでなく， 咬合位の変化に伴う筋の長さや走行などの解剖学 的要素も関連すると考之られる。

本研究では，各高径で咬合位を左右的に偏位さ せた場合，すべての被験者で $\mathrm{AI}$ は高径が小さい ほど顕著に変化した。条件 1 の HP から $1 / 4 \mathrm{R}, 1 /$ $4 \mathrm{~L}$ の実長は平均 $1.4 \mathrm{~mm}$ であるが，このときの 変化度は AT で-7.8〜12.0, PT で-23.0〜 -34.4 で, ATについては $1 / 2 \mathrm{R}, 1 / 2 \mathrm{~L}$ の場合の 1.5 倍, PT では 1.9 倍で，この狭い範囲で筋活動は急激

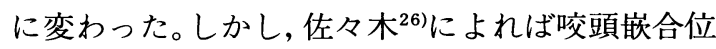
を 0.5 2.0 mm 側方偏位させた義歯では 1 週間 の装着で嵌合位の側方偏位の方向，量を知ること はきわめて困難であったという。歯の欠損や咬合 再構成でこの程度の咬合位の偏位が生じることは 実際上ありうる。しかし，機能的不調和による筋 活動の左右のアンバランスは患者の適応の程度に
よっては不快症状をひき起こす可能性がある。 よって，咬頭嵌合位は側方に偏位しないことが重 要であるが, 本研究結果からすると, HP から少な くとも $1 / 4 \mathrm{R}, 1 / 4 \mathrm{~L}$ の範囲内におさめることが必 要である。

本研究は咬頭嵌合位に対する筋機能の側方的許 容度を明らかにしようとしたものであるが咬合診 断，咬合再構成にとって有効な示唆を与えること ができたと考えられる。

\section{V. 結 論}

咬頭嵌合したときの下顎の垂直的，左右的な位 置が咀嚼筋（咬筋，側頭筋前部，側頭筋後部）の 機能に及ぼす影響を明らかにするため， 5 人の被 験者にスプリントにより種々の咬合位を付与し， 本来の咬頭嵌合位 IP での最大咬みしめ時の筋活 動量の $50 \%$ の強さで，これらの咬合位およびIP で咬みしめを行わせて筋活動量を記録測定し，下 顎位との関係を検討した結果，以下のような結論 を得た。

\section{1. 咬合位を垂直的に変化させた場合}

1）多くの被験者で, 側頭筋後部の活動量が減 少した。

2 ）各筋の左右側の筋活動の均衡性は一定しな かった。

\section{2. 咬合位を左右的に変化させた場合}

1 ）左右同名筋で比較した場合，側頭筋前部， 後部では偏位側で筋活動が大きくなり，反対 側では小さくなる傾向が認められた。

2 ）咬筋の活動は被験者により傾向が分かれ, 偏位側で大きくなり，反对側で小さくなる傾 向を示すものと，明瞭な傾向を示さないもの とがあった。

3 ) 側頭筋前部, 後部で左右の筋活動の均衡は, 咬合高径が大きい場合には変化がわずかで あったが，高径が小さい場合には正中付近で 大きく変化し, 左右側の筋活動の均衡性は IP 付近において鋭敏であることが示された。 


\section{謝辞}

稿を終えるに臨み，ご想切なるご指導とご校閲を賜 クました藍＼cjkstart稔教授に謹んで感謝の意を表します。 また本研究に際し，ご援助，ご協力をいただきました 第 1 歯科補緅学教室の諸先生方ならびに被験者の皆 様に心からお礼申し上げます。

本研究の一部は, 平成 4 年 10 月 23 日, 第 88 回日本 補経歯科学会学術大会 (東京), 1993 年 5 月 15 日, Society of Oral Physiology 18 th Conference (Gentofte, Denmark）において発表した。

\section{文献}

1）藍 稔：顎機能異常一咬合からのアプローチ. 東京, 1983，医歯薬出版，159-189.

2）森 隆司，小野 積，服部正巳，川口豊造：咬頭 嵌合位の様相と顎口腔系の機能について. 下顎運 動機能と EMG 論文集 $1: 81-86,1982$.

3）森 隆司，甲藤克彦，川口豊造：顎機能に占める 咬頭嵌合位の意義。下顎運動機能と $E M G$ 論文集 $3: 189-194,1984$.

4) Boos, R. H. : Intermaxillary relation established by biting power. J. Amer. Dent. Assoc. $27: 1192-1199,1940$.

5) Willis, F. M. : Features of the face involved in full denture prosthesis. Dent. Cosmos 77 : 851-854, 1935.

6) Niswonger, M. E. : The rest position of the mandible and the centric relation. J. Amer. Dent. Assoc. 21 : 1572-1582, 1934.

7) Lytle, R.B. : Vertical relation of occlusion by the patient's neuromuscular perception. J. Prosthet. Dent. $14: 12-21,1964$

8) Schuyler, C. H. : Intra-oral method of establishing maxillomandibular relation. J. Amer. Dent. Assoc. 19 : 1012-1021, 1932.

9) Greene, F. A. : Getting central occlusion. Dent. Dig. $33: 476,1927$.

10) Gysi, A. : The problem of articulation. Dent. Cosmos 52:1-19, 1910

11) Silverman, M. M. : Centric occlusion and jaw relations and fallacies of current concepts. J. Prosthet. Dent. $7: 750-769,1957$.

12) Posselt, U. : Physiology of occlusion and rehabilitation, 2 nd ed. Oxford, 1968, Blackwell scientific publications, 39-53.

13）川口豊造：電気的測定装置による習慣的閉口運 動および嬩下運動時の歯牙接触位に関する研究. 補緅誌 $12: 398-423,1965$.

14）山下 敦, 井上 宏：マンディブラーキネジオグ
ラフーその原理と使用法, 臨床応用一. DE 41： $1-15,1977$.

15）会田栄一，小野俊朗，今村基遵，石黒裕茂，安立 妙子, 黒須一夫：下顎運動解析装置 K 6 ダイアグ ノスティックシステムにおける基礎的検討，第 1 報 記録精度. 愛院大歯誌 $26: 195-202,1988$ 。

16）吉本眞人：下顎の急速開閉反復運動による新規 設定咬頭嵌合位への運動制御能に関する実験的 研究. 歯科学報 $84: 1315-1364,1984$.

17) Prium, G. J., TEN Bosch, J. J. and DE Jongh, H. J. : Jaw muscle EMG-activity and static loading of the mandible. J. Biomech. 11: 389-395, 1978.

18) Clarke, N. G., Townsend, G. C. and Carey, S. E. : Bruxing patterns in man during sleep. J. Oral Rehabil. 11:123-127, 1984.

19）吉田 実, 野首孝柌, 守光 隆, 長島 正, 山本 誠, 安井 栄, 喜多誠一, 吉備政仁, 奥野善彦: 咀嚼筋の左右差に関する臨床的評価。日顎誌 $4: 59-72,1992$.

20) Naeije, M., McCarroll, R. S. and Weijs, W. A. : Electromyographic activity of the human masticatory muscles during submaximal clenching in the inter-cuspal position. J. Oral Rehabil. $16: 63-70,1989$.

21) Visser, A., McCarroll, R. S. and Naeije, M. : Masticatory muscle activity in different jaw relations during submaximal clenching efforts. J. Dent. Res. $71: 372-379,1992$.

22) Ferrario, V. F., Sforza, C., Miani Jr, A., D' Addona, A. and Barbini, E. : Electromyographic activity of human masticatory muscles in normal young people. Statistical evaluation of reference values for clinical applications. J. Oral Rehabil. $20: 271-280,1993$.

23）坂本正朔：補緅学領域における下顎の垂直的な らびに水平的変位に関する筋電図学的研究. 九州 歯会誌 $23 ： 544-572,1969$.

24) McCarroll, R. S., Naeije, M., Kim, Y. K. and Hansson, T. L.: The immediate effect of splint-induced changes in jaw positioning on the asymmetry of submaximal masticatory muscle activity. J. Oral Rehabil. $16: 163-170$, 1989.

25）古屋元之：咬合力と咀嚼筋の筋放電との関係に ついての実験的研究, 第 2 報 左右側的条件につ いて。歯科学報 $84: 1367-1422,1984$.

26）佐々木眞澄：新規設定側方咬頭嵌合位に対する 下顎咀啷運動の順応に関する実験的研究. 歯科学 報 $89 ： 931-980,1989$. 